\title{
The urban climate of Budapest: past, present and future
}

\author{
FERENC PROBÁLD ${ }^{1}$
}

\begin{abstract}
Since the groundbreaking survey of Budapest's urban climate in 1974, little has been done to reveal how the summer heat island of the city has changed. During the last couple of decades, the impact of the anthropogenic heat release due to the spectacular expansion of automobile traffic and the widespread use of air conditioners may have added an estimated $1-1.5{ }^{\circ} \mathrm{C}$ to the temperature surplus of the city. As an evidence of the large-scale climate change, the homogenized temperature record of Budapest shows a strongly growing frequency and persistence of severe heat waves plaguing city dwellers. Regional models predict rising temperatures with more pronounced summer warming until 2100 in the Carpathian Basin. Therefore, the cooler local climates of the Danube islands and the Budai Hills should be appreciated as valuable environmental assets to be saved by more reasonable land use policies and stricter property development regulations.
\end{abstract}

Keywords: Budapest, urban climate, heat island, climate change, urban land use

\section{The background: physiography and structure of the city}

Budapest with its more than 1.7 million inhabitants is one of the largest and economically most dynamic cities in East Central Europe and stands out as the indisputable political, administrative and cultural centre of Hungary. It is situated on the banks of the Danube River, which crosses the city in a northsouth direction, and divides it into a western (Buda) and eastern (Pest) part. The eastern side is flat, and the unimpeded spread of the built-up area has resulted in a quite regular morphological pattern, which can easily be described by the well-known urban model of concentric zones. The city centre (CBD) is surrounded by a densely built-up inner residential belt consisting of mostly dilapidated housing stock from the late $19^{\text {th }}$ and early $20^{\text {th }}$ centuries interspersed with neighbourhoods at different stages of renewal. The transi-

${ }^{1}$ Professor emeritus, Department. of Regional Science, Eötvös Loránd University, H-1112 Budapest, Pázmány P. sétány 1. E-mail: probald@caesar.elte.hu 
tional zone embraces large derelict industrial areas: a rust belt at various stages of transition toward tertiary and residential functions, as well as some huge, monotonous housing estates with prefabricated high-rise buildings from the socialist era. In the outer residential belt of former suburbs, joined to the capital in 1950 giant housing estates also appear. This belt is dominated by detached family houses surrounded with small gardens.

On the west (Buda) side of the Danube River the somewhat delayed development and the emerging irregular pattern of the city have been due to the complicated orography. The Budai Hills rise to an altitude of more than $500 \mathrm{~m}$ (that is about $400 \mathrm{~m}$ above the level of the Danube River). The hilltops and the upper parts of the slopes are still covered by recreational forests forming a protected area, while most of the slopes were built up during the last century with good quality 4-5-storey houses surrounded by more or less green areas. High-density residential areas and large housing estates barely appear on the slopes; they are mostly restricted to the foothills and the minor plains adjacent to the Danube River.

Despite the heavy loss of vegetation due to extensive housing construction, the slopes of the Budai Hills are still sources of a frequently occurring night-time mountain breeze, which can mitigate the summer heat of the city by conveying cleaner and cooler air towards the densely built up areas. The tectonically preformed, NW-SE directed valleys are in good accordance with the prevailing wind direction and they serve, together with the Danube valley, as natural ventilation channels. The relief and the morphology of the city result in a great complexity of local climates, where the characteristic features of an urban temperature regime can be best detected and studied on the flat, densely built up eastern part of Budapest.

\section{Climatological data: sources and constraints}

Systematic meteorological measurements started in 1779 in Buda which was the southeastern outpost of the observatory network organised by the Palatine Meteorological Society of Mannheim. Thus, by now we have air temperature measurement records embracing more than 230 years with reliable data, which were homogenised by the scientists of the National Meteorological Service in order to eliminate errors and minor alterations that could be ascribed to repeated relocations and changes in the instrumentation of the station, as well as to the growth of the surrounding city that had taken place in the meantime. These data were first thoroughly evaluated by RéTHLY, A. (1947) in a pioneering work, which provided a fine assessment of all major macro-climatic features of the capital city of Hungary.

The first network for the purpose of measuring air pollution in Budapest was established by the National Institute for Public Health in 1958. The scope of its programme has been steadily broadened and its instrumentation improved sev- 
eral times accordingly. At present the National Air Pollution Monitoring Network operates stations equipped with automatic instruments at 12 points of Budapest, complemented by manual sampling at regular intervals on 15 additional sites. The task of the network comprises monitoring the concentration of $\mathrm{SO}_{2^{\prime}} \mathrm{NO}_{2^{\prime}} \mathrm{NO}_{x^{\prime}} \mathrm{CO}$, ozone and particulate matter, thus providing an overall perspective on the actual and average state of ambient air quality in different parts of the city.

In the $20^{\text {th }}$ century regular meteorological observations and instrumental measurements were started and continued for a shorter or longer period at 24 different sites within the present borders of Budapest. The data obtained at these stations could be used to throw light on local differences in the climate of the city. However, among these stations only one was located in the proper core of the city, within the large, grass-covered courtyard of the City Council Building (Madách Square). Measurements at this site were performed between 1965 and 1969, thus providing a database appropriate to reveal the properties of urban climate and to compare these with the natural background climate represented by the Pestlőrinc Observatory of the Hungarian Meteorological Service, located at the remote South-Eastern rim of the old suburban belt. By taking advantage of all the available, mostly unpublished datasets of the Hungarian Meteorological Service, the local differences and the particular urban features of the climate were first described and analysed in Budapest by Probáld, F. (1974).

Owing to financial difficulties the scope of meteorological measurements in Budapest has witnessed a sharp reduction since 1970 with only four stations remaining from the former network, none in the city centre. Hence, urban climate research has practically been abandoned in Budapest except for some attempts to utilise satellite imagery for studying the heat island (BARTHOLY, J. et al. 2005). Satellite measurements, however, cannot produce continuous data records and they provide information merely about the temperature of the surface instead of the ambient air at a height of $2 \mathrm{~m}$. Since these figures can be quite different from each other, remote sensing is not a feasible substitute for field observations. Therefore, in describing the intensity and temporal changes of the urban heat island in the next section, we have to rely on the hourly breakdown of thermograph records taken in the 1960s at the station located in the city centre and from the Pestlörinc Observatory. Nevertheless, recent changes in the macro-scale climate of Budapest allow us to draw some conclusions concerning the actual state and the future of the urban environment, too.

\section{The heat island of Budapest in retrospect}

Ever since its first scientific demonstration by L. HowARD in London in the early $19^{\text {th }}$ century, the urban heat island has received keen attention from cli- 
matologists realising the significance of this phenomenon from both theoretical and practical points of view. The spatial pattern and temporal changes of the heat island are determined by a great variety of factors, such as location, background climate and weather conditions, size of the city, the fabric of roads, buildings, parks, and their geographical distribution over the urbanized area. Consequently, the thermal regime of each city is more or less unique, thus it deserves careful study. In Budapest, key features of the heat island, represented by the temperature surplus of the urban core compared to surrounding areas, can be summarised as follows.

The annual mean temperature in Budapest downtown is $1.2^{\circ} \mathrm{C}$ higher than outside the city. The annual cycle of urban-rural temperature difference reaches a peak in January $\left(1.5^{\circ} \mathrm{C}\right)$ and a second one in July $\left(1.3^{\circ} \mathrm{C}\right)$. March, which is usually quite windy and cloudy, is characterised by a minimum in the temperature surplus of the city $\left(1.0^{\circ} \mathrm{C}\right)$. By establishing the monthly means of its components, early enquiries about the surface energy balance in Budapest revealed the physical background of the urban heat island (Рroвáld, F. 1971). The summer warming of the city can be explained mainly by a higher direct turbulent heat transfer to the air, which is due to the decrease in evaporation and, consequently, in latent heat transfer as well. In winter the heat released by human activities can be regarded as the key factor shaping the temperature difference between the city and its surroundings. While city dwellers are certainly not displeased with a warmer environment in winter, they may feel quite different in the hot season when human comfort is adversely influenced by the diurnal variation of heat island intensity.

The rugged urban surface made up of massive concrete and stone structures is able to absorb large amounts of solar radiation during the day, store this energy and release it to the atmosphere at night. This process leads to a substantial delay of the diurnal temperature cycle and results in a characteristic variation in the intensity of the urban heat island: the minimum difference in urban-rural temperatures is observed late in the morning and the peak of about $2{ }^{\circ} \mathrm{C}$ in the evening, a difference that remains for most of the night (Figure 1). For the same reasons, similar daily temperature regimes were

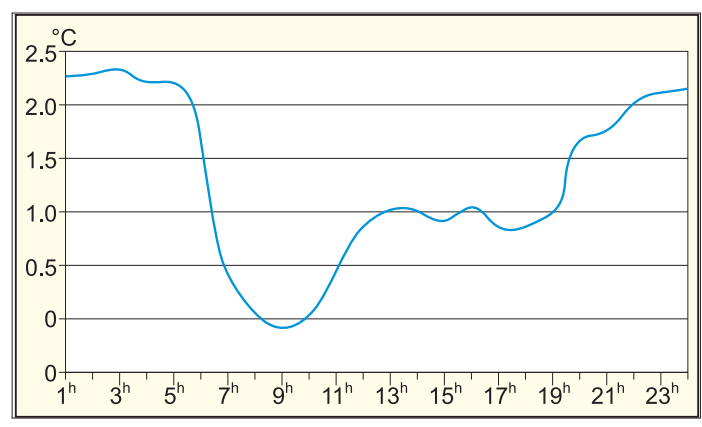
detected by measurements performed in other cities, too.

Fig. 1. Diurnal cycle of the difference in temperature between the downtown (City Council) and suburban outskirts (Pestlőrinc) in July (19651967). Source: ProbÁLD, F. 1974. 
Cloudy and windy weather conditions slightly weaken the urban heat island, whereas on clear, sunny days it gets stronger and the urban-rural temperature difference may exceed the average figures by several tenths of a degree with a tendency of further growth during periods of lasting heat waves. There are also remarkable micro-climatic differences within the densely built up area of the city. This has been demonstrated for example by measurements which were performed on three consecutive clear and hot days in July 1966 at a height of 2 metres above a safety island in the middle of Madách Square, located in downtown Budapest. The air of the large square lacking any greens and permanently exposed to sunshine was found to be warmer by roughly 1 ${ }^{\circ} \mathrm{C}$ than the nearby grassy courtyard of the City Council throughout the afternoon and the evening. In comparison with rural areas the difference amounted to $3^{\circ} \mathrm{C}$. The human comfort in such urban spaces is adversely affected, and the stress is increased also by thermal radiation emitted by the pavement and the walls of the buildings, which are even warmer than the adjacent air.

The calm and clear anticyclonic weather, characteristic for lasting heat periods, is often coupled with the accumulation of various pollutants in the ambient air of the city. The bulk of these pollutants, such as $\mathrm{NO}_{2}$, the wellknown precursor of ozone, as well as $\mathrm{CO}$ and particulate matter of various sizes come from heavy car traffic. Concentration of ozone exceeding the alert level in summer, similarly to dangerous levels of fine particulate matter in winter, occurred several times during the last couple of years. Heat alerts became even more frequent.

\section{The prospect: rising heat stress in the city}

After a steady decline for more than two decades, the population of Budapest today is not larger than it was fifty years ago. During its last period of growth in the 1970s and early 1980s, however, large housing estates were built in the former industrial and suburban belts of the city. These constructions certainly had some impact on the microclimate of their surroundings, but they could hardly bring about significant changes in the intensity and meso-scale pattern of the heat island. Meanwhile, the city witnessed the emergence of at least three new factors that are likely to affect the present and future features of the urban climate: the spread of vehicle traffic, the use of air conditioners and the impact of changes in the regional climate.

Tremendous changes have taken place in the quality of the fuel used in the city, too. Until the early 1960s the heating of the dwellings were largely based on coal, which caused frequent winter smog due to the accumulation of sulphur dioxide and soot particles in the air. In the subsequent decade, however, coal burning was quickly and almost totally replaced by natural gas. 
This was done for pure economic reasons, but as a favourable side effect, air quality greatly improved. Nevertheless, this success was largely offset by the spectacular expansion of automobile traffic over the last decades that probably peaked recently, at least in the inner city, where more measures have been implemented to reduce traffic congestion. Thus, transportation as a whole has become the major source of air pollution and it is heavily contributing to anthropogenic heat release concentrated along the main traffic routes.

The last one or two decades have also witnessed the increased use of air conditioners in Budapest, responsible for a new summer peak of electricity consumption. This process is mainly due to technical development and higher living standards, but the urge to mitigate the indoor impact of the more frequently occurring heat waves cannot be disregarded either. At the same time, air conditioning systems produce a positive feedback that may strengthen the heat stress of outdoor urban climate, particularly on the hottest summer days and in the most densely built up areas.

During the last couple of decades numerous attempts were made to quantify the anthropogenic heat emission of transportation and of the buildings in several cities (e.g. in Tokyo and Philadelphia). The methods and conclusions of these surveys have recently been reviewed by SAILOR, D.J. (2011). According to the building model calculations of SEPRődi-EGERESI, M. and ZöLD, A. (2011), the summer daily heat output of the houses in the densely built up inner city of Budapest would amount to a territorial average of $45 \mathrm{~W} / \mathrm{m}^{2}$. Another starting point is offered by the electricity consumption data of the utility company MAVIR.

The national consumption figures for the heat wave in June 2013 were higher by 20,000 MWh/day than on an average weekday in May. The difference can largely be attributed to the use of air conditioners. Since about 10\% of the increase may appear in the inner city of Budapest $\left(30 \mathrm{~km}^{2}\right)$, our estimate suggests a heat output amounting there to $25-30 \mathrm{~W} / \mathrm{m}^{2}$ from this source alone. Both of the above estimates ignore, however, the heat emission of the traffic which falls in most cities considerably behind the energy consumption of the buildings (SAILOR, D.J. 2011). Based on the inquiries in cities with a climate more or less similar to Budapest, we can assume that the combined meso-scale impact of the vehicle traffic and the air conditioning systems have resulted in an additional urban summer air temperature rise of $1.0-1.5^{\circ} \mathrm{C}$ since the $1960 \mathrm{~s}$. Though this difference itself is certainly not negligible, the threat coming from recent changes in macro-scale climate and weather conditions put the issue of urban heat stress in an even more sinister perspective (STONE, B. 2012).

These changes have manifested themselves in the growing frequency (Figure 2) and longer persistence (Figure 3) of heat waves (VINCZE, E. et al. 2013). The figures reveal rather worrying trends in the homogenised temperature record of Budapest. However, the station of the Hungarian Meteorological Service, which is located on the Buda side in a densely built up neighbour- 


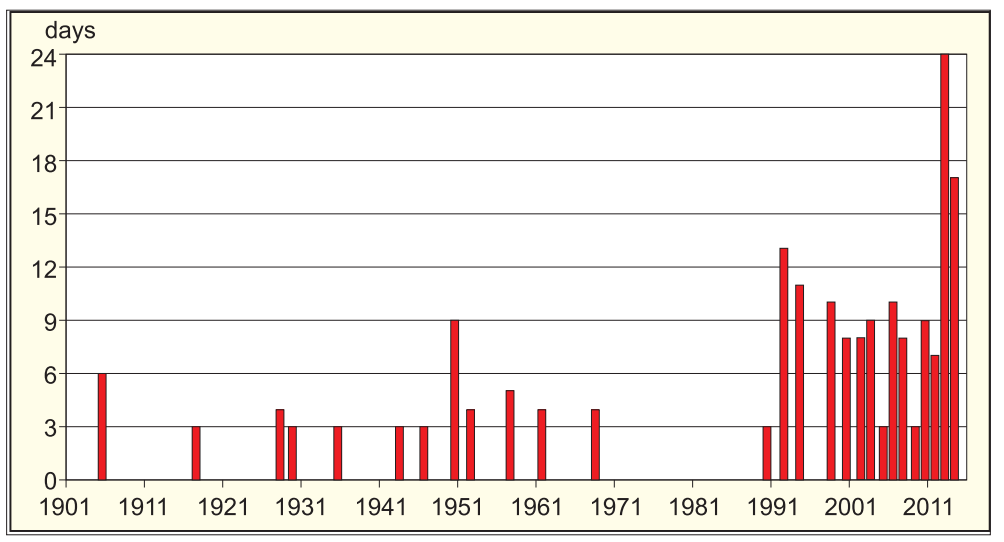

Fig. 2. Annual number of days in heat periods (daily mean temperatures higher than $27^{\circ} \mathrm{C}$ on three consecutive days). Source: Vincze E., Lakatos, M. and Tóth Z. 2013.

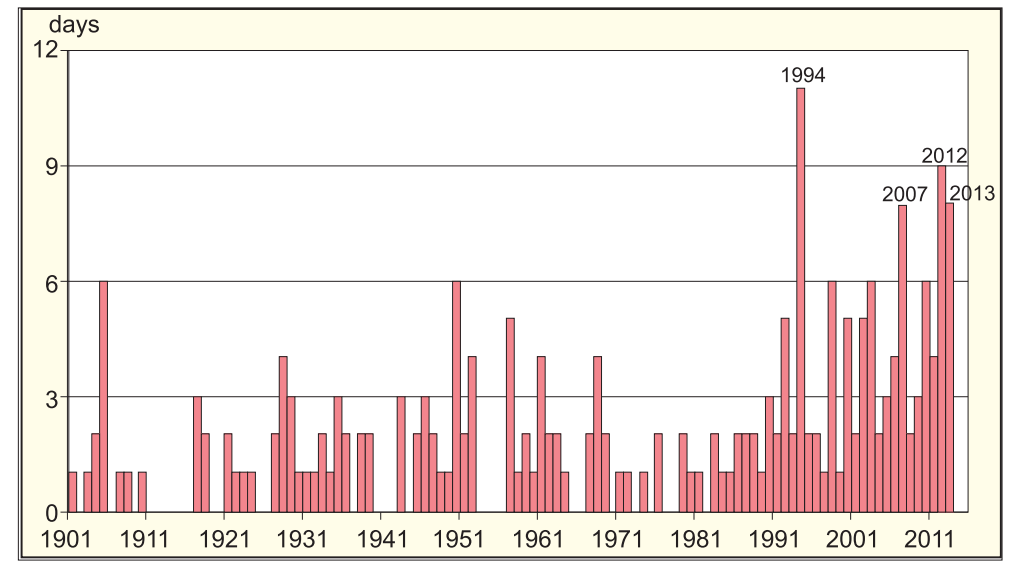

Fig. 3. Persistence (in days) of the most lasting heat waves in the given years (daily mean above $27^{\circ} \mathrm{C}$ ) Source: Vincze, E., Lakatos , M. and Tóth, Z. 2013.

hood, shows about $0.5^{\circ} \mathrm{C}$ lower temperature than the city centre. The daily mean exceeding here $27^{\circ} \mathrm{C}$ on three consecutive days indicates the threshold of the most serious $3^{\text {rd }}$ grade heat alert in the city.

According to the most likely scenarios of regional model estimates, temperatures in the Carpathian Basin are bound to rise in accordance with the medium projection of the IPCC (2007). However, warming will be more distinct in the summer with an expected temperature increase of at least $4{ }^{\circ} \mathrm{C}$ until 2071-2100 against the reference period at the end of the $20^{\text {th }}$ century (BARTHOLY, J. et al. 2007, 2011). This change will be coupled with a dramatic increase in the 
frequency of heat waves. The annual number of hot days $\left(t_{\max } \geq 30^{\circ} \mathrm{C}\right)$ will triple during the $21^{\text {st }}$ century, thus getting 34-38 days higher than the average of 18 days registered in the last 30 years of the millennium. (BARTHOLY, J. et al. 2011; VINCZE, E. and SzÉPszó, G. 2012). These are merely average figures, which do not take into account the additional warming effect of the city.

\section{Climatic assets to be saved}

It is hard to admit, but except for some measures with micro-scale impacts only, in a city with an inherited rigid structure like Budapest, precious little can be done to change the general characteristics of urban climate in order to cope with the trend of global warming and to relieve the growing thermal stress that people will suffer from in summer. Therefore, one has to pay special attention to those areas where natural conditions are more or less able to counterbalance the discomfort caused by the typical urban climate. Within the confines of Budapest one can find two areas with particularly favourable atmospheric conditions, namely the banks and small islands of the Danube River and the Budai Hills with their great variety of microclimates. The remarkable differences compared to the downtown were reflected even by monthly mean temperatures in the 1960s (Table 1) and they must have substantially grown since that time.

Table 1. Deviations of the monthly mean temperatures between 1954 and 1968 on Szabadság Hill $^{*}$ and Margaret Island ${ }^{* *}$ from those of the city centre/City Council ${ }^{* * *}$ in ${ }^{\circ} \mathrm{C}$

\begin{tabular}{c|c|c|c|c|c|c|c}
\hline Site & April & May & June & July & August & September & Year \\
\hline Margaret Island & -1.0 & -1.3 & -1.6 & -1.7 & -1.6 & -1.7 & -1.2 \\
Szabadság Hill & -2.9 & -3.2 & -3.2 & -3.1 & -2.8 & -2.7 & -2.9 \\
\hline
\end{tabular}

Height: ${ }^{*} 470 \mathrm{~m}$ a.s.l., ${ }^{* *} 103 \mathrm{~m}$ a.s.l., ${ }^{* * *} 105 \mathrm{~m}$ a.s.l. Source: ProbÁLD, F. 1974.

In calm, sunny anticyclonic weather one can measure afternoon and evening temperature differences between Margaret Island and large down-

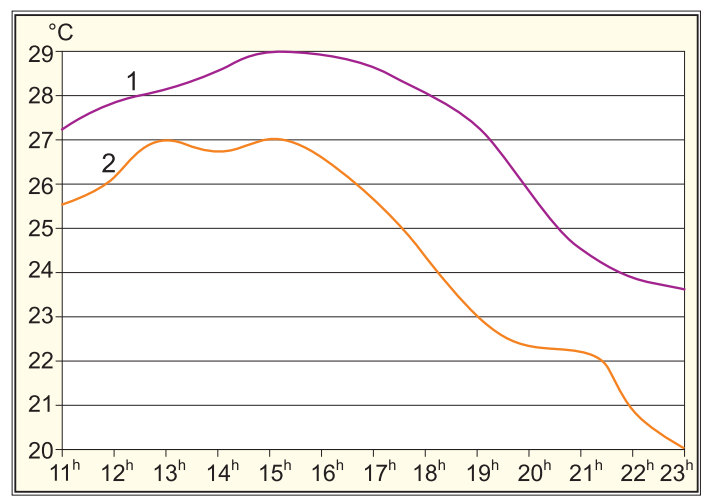
town squares more than 2 times higher than monthly means (Figure 4).

Fig. 4. Diurnal change of the air temperature on the safety island of Madách Square (1), and the park of Margaret Island (2); average of field measurements on three consecutive summer days in 1966. Source: РRobáld, F. 1974. 
Under similar conditions surface temperature differences reaching $8-10{ }^{\circ} \mathrm{C}$ between the downtown and Margaret Island as well as between the downtown and the Budai Hills are quite usual as it has been demonstrated by satellite measurements (BARTHOLY, J. et al. 2005). This is of course also linked with less frequency and shorter persistence of heat periods when daily peaks exceed $30{ }^{\circ} \mathrm{C}$ and night-time lows are higher than $20^{\circ} \mathrm{C}$.

Thus, the population dwelling in the hilly districts of Buda suffers much less from summer heat, while it can enjoy more sunshine and snow in winter. Due to prevailing west winds, the air is much cleaner on the Buda side, and severe air pollution is restricted to the key traffic routes that follow the main valleys. There is abundant evidence provided by recent polls and actual real estate prices that districts in Buda have the highest prestige and stand out among the favourite target locations of those intending to move, while there are only few people willing to leave Buda for the sake of a new dwelling in Pest. The equally easy access to nature and to the city centre, the various amenities provided by the Budai Hills are remarkable assets for the Hungarian capital even in the international competition of cities, since supply of quality dwellings and environmental issues rank high among the priorities of postmodern societies.

Regrettably enough, the development of land use during the second half of the $20^{\text {th }}$ century largely disregarded the limited extent and particular value of the natural endowment of this area. The orchards, vineyards and nice gardens of the $19^{\text {th }}$ century have receded and the rest of the forests have been encroached upon by construction with functions that simply do not fit to this environment, but are now difficult to remove. In the 1970s and 1980s large prefabricated housing estates appeared and high-rise buildings were erected on the slopes. As most obvious examples of the misuse of environmental assets, military barracks, institutions of higher education and training of the police and the army, as well as nuclear research facilities still occupy considerable areas in the Budai Hills, which should have been saved for more reasonable purposes.

From the islands of the Danube River, Margaret Island with an area of 96.5 hectares is the closest to the city centre. The whole island is a beautiful park suitable for walking, jogging, and other leisure time activities. Beyond several sports facilities one can also find a wellness hotel there taking advantage of the thermal water from local wells for medical purposes. Thus, the island has become a favourite public place and its amenities are properly utilised, sometimes even crowded with a great number of visitors. While Margaret Island is threatened by eventual overuse, the advantages offered by two similar islands situated a bit further northwards (Óbuda Island, Nép Island) seem to be located almost idle in lack of reasonable management and development strategies which would serve public interests. This can be most 
clearly exemplified by the southern half of Óbuda Island, which has been sold to a foreign-owned development company wanting to build there a high-rise hotel, casinos and a large-scale entertainment centre. This highly controversial project, however, has been pending for about ten years already.

The banks of the main branch of the Danube River have a total length of $58 \mathrm{~km}$ within the confines of Budapest. In a survey conducted in 2007 by using both field trips and aerial photos we have found that the total length of densely built up areas amounted to 18.6 km (Izsák, É., Probáld, F. and Uzzoli, A. 2008). The embankments serve here as the main N-S directed arterial traffic roads and they are bordered by a dense row of tall buildings that blocks any air exchange between the water surface and the nearby streets. Opening direct access to the cool and nice riverside for pedestrians has been envisaged several times, but the problem is still to be solved.

Derelict and entirely abandoned industrial establishments of the brownfield belt occupy $16 \mathrm{~km}(27.6 \%)$ of the banks, while sections of altogether 12.4 $\mathrm{km}(21.4 \%)$ length seem to be void of any reasonable human use, though even here the willow and poplar groves of the floodplain fulfil a valuable ecological function as wildlife corridors. At some places on Csepel Island the potential use of the riverside is restricted because of the vicinity of wells providing piped water for the city. In most cases, however, the key obstacle of utilisation is the lack of flood control levees or the heavy pollution of the soil. To overcome these difficulties considerable investments would be required from property developers.

Nevertheless, the brownfield belt and other idle sections of the riverside still offer great perspectives for future development. At the turn of the century the opportunities of profitable investments also aroused the interest of some large foreign-owned real estate companies, which started to construct gated communities with luxury apartment houses at the river, taking advantage of the favourable environment and the magnificent vista to be enjoyed at the sites selected for development. However, the drive to make as much profit as possible is manifested in the extreme density of buildings, the shortage of greens, and sometimes the quite dull architecture of these projects (KAUKO, T. 2012). The realization of further grandiose development plans were brought to a temporary halt in 2008 by the economic crisis and its disastrous impact on the real estate market.

\section{Conclusion}

Metropolitan growth and climate change have brought about new global ecologic conditions (SASSEN, S. 2013). Thus, monitoring future changes in urban climate and adaptation to the trends has become more necessary than ever. 
Much more responsibility would be required also in preparing decisions with regard to the values of environment. In Budapest the ultra-liberal mayor and council leading the city between 1990 and 2010 adopted a laissez-faire attitude, thus allowing private development companies to get through their interests at the expense of those of the whole urban community. In order to save the environmental assets of Budapest and to achieve a turn toward sustainability, reasonable property development, better governance, comprehensive planning, appropriate regulation measures as well as their rigorous implementation are needed.

\section{REFERENCES}

Bartholy, J., Bozó, L. and Haszpra, L. eds. 2011. Klímaváltozás. Klímaszcenáriók a Kárpátmedence térségére (Climate change. Scenarios for the Carpathian Basin). Budapest, MTA-ELTE Meteorológiai Tanszék, 281 p.

Bartholy, J., Dezsó, Zs. and Pongrácz, R. 2005. Satellite-based analysis of the urban heat island effect. Idójárás 109. 217-232.

Bartholy, J., Pongrácz, R. and Gelybó, Gy. 2007. Regional Climate Change expected in Hungary for 2071-2100. Applied Ecology and Environmental Research 5. (1): 1-17.

IPCC 2007: Climate Change 2007. Synthesis Report. Geneva, IPCC.

Izsák, É., Рrobáld, F. and Uzzoli, A. 2008. Természeti adottságok és életminőség Budapesten (Natural endowments and quality of life in Budapest). Debrecen, IV. Magyar Földrajzi Konferencia, 265-270.

Kauko, T. 2012. An Institutional Analysis of Property Development, Good Governance and Urban Sustainability. European Planning Studies 20. (12): 1-19.

MAVIR 2013: www.mavir.hu/web/mavir/adatpublikacio. Retrieved on the 30. 7. 2013.

Рrobáld, F. 1971. The Energy Balance as the Basis of the Urban Climate of Budapest. Annales U. Sc. Eötvös Sectio Geographica VII. 51-68.

Probáld, F. 1974. Budapest városklímája (The urban climate of Budapest). Budapest, Akadémiai Kiadó, 127 p.

Réthly, A. 1947. Budapest éghajlata (The climate of Budapest). Budapest, Rheuma- és Fürdőkutató Intézet, 147 p.

SAILOR, D.J. 2011. A review of methods for estimating anthropogenic heat and moisture emissions in the urban environment. International Journal of Climatology 31. 189-199.

SASSEN, S. 2013. Bridging the ecologies of cities and nature. http://portal.unesco.org/en/files46764. Retrieved on 7. 7. 2013.

SePrốd-Egeresi, M. and ZöLD, A. 2011. Buildings' heat output and urban climate. Acta Climatologica and Chorologica Univ. Szegediensis 44-45. 103-110.

Stone, B. 2012. The City and the Coming Climate. Climate Change in the Cities we Live. Cambridge, Cambridge Univ. Press, 198 p.

VInCZE, E. and SzéPszó, G. 2012. Az elmúlt nyár értékelése a mérési adatok és a jövóben várható változások tükrében (Evaluation of the measurement records of this summer and the changes expected to come in the future). http://klimabarat.hu/node/489. Retrieved on 11. 11. 2012.

VinCZE, E., LAKATOS, M. and Tóth, Z. 2013. 2013 nyaránakéghajlati áttekintése (Climatological overview of the summer 2013). http:// klimabarat.hu/node/591. Retrieved on 3. 11. 2013. 


\title{
Ukraine in Maps
}

\author{
Edited by: Kocsis, K., Rudenko, L. and Schweitzer, F.
}

\author{
Institute of Geography National Academy of Sciences of Ukraine \\ Geographical Research Institute Hungarian Academy of Sciences. \\ Kyiv-Budapest, 2008, 148 p.
}

Since the disintegration of the USSR, the Western world has shown an ever-growing interest in Ukraine, its people and its economy. As the second-largest country in Europe, Ukraine has a strategic geographical position at the crossroads between Europe and Asia. It is a key country for the transit of energy resources from Russia and Central Asia to the European Union, which is one reason why Ukraine has become a priority partner in the neighbourhood policy of the EU. Ukraine has pursued a path towards the democratic consolidation of statehood, which encompasses vigorous economic changes, the development of institutions and integration into European and global political and economic structures. In a complex and controversial world, Ukraine is building collaboration with other countries upon the principles of mutual understanding and trust, and is establishing initiatives aimed at the creation of a system that bestows international security.

This recognition has prompted the Institute of Geography of the National Academy of Sciences of Ukraine (Kyiv) and the Geographical Research Institute of the Hungarian Academy of Sciences (Budapest) to initiate cooperation, and the volume entitled "Ukraine in Maps" is the outcome of their joint effort. The intention of this publication is to make available the results of research conducted by Ukrainian and Hungarian geographers, to the English-speaking public. This atlas follows in the footsteps of previous publications from the Geographical Research Institute of the Hungarian Academy of Sciences.

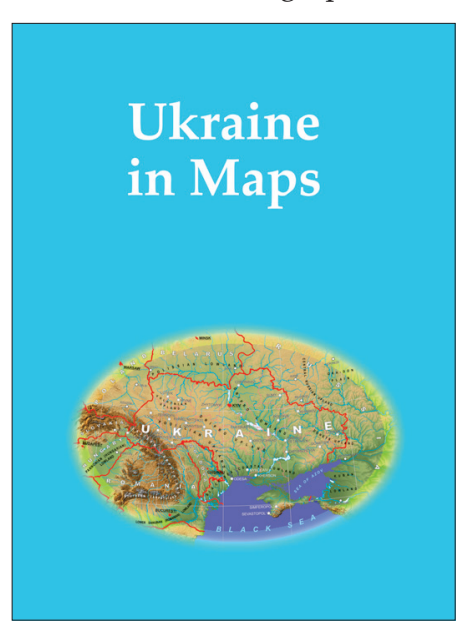
Similar to the work entitled South Eastern Europe in Maps $(2005,2007)$, it includes 64 maps, dozens of figures and tables accompanied by an explanatory text, written in a popular, scientific manner. The book is an attempt to outline the geographical setting and geopolitical context of Ukraine, as well as its history, natural environment, population, settlements and economy. The authors greatly hope that this joint venture will bring Ukraine closer to the reader and make this neighbouring country to the European Union more familiar, and consequently, more appealing.

Price: EUR 35.00

Order: Geographical Institute RCAES HAS Library

H-1112 Budapest, Budaörsi út 45.

E-mail: magyar.arpad@csfk.mta.hu 